\title{
4. HOLE 956B: DOWNHOLE FMS MEASUREMENTS IN THE SOUTHERN VOLCANIC APRON OF GRAN CANARIA, CENTRAL ATLANTIC ${ }^{1}$
}

\author{
Nicolas Binard, ${ }^{2}$ Hans-Ulrich Schmincke, ${ }^{2}$ and Mari Sumita ${ }^{2}$
}

\begin{abstract}
Hole 956B penetrated a total of $700 \mathrm{~m}$ of biogenic and volcaniclastic sediments into the southwestern peripheral volcanic apron of Gran Canaria. Electrical microconductivity measurements, made by the Formation MicroScanner (FMS) tool, were recorded from 701 to $283 \mathrm{mbsf}$. The cumulative curve and frequency distribution of the FMS data are clearly bimodal, showing two main families: biogenic sediment and volcaniclastics (tuffs and volcanic breccia). As suggested by the cumulative conductivity curve, tuffs and volcanic breccia could not be distinguished from each other as their electrical conductivities are too similar to be reliably differentiated.

About $54.9 \%$ of the total FMS values represents volcaniclastics comparable to that derived from the core estimate (53.8\%). We attribute this to the fact that volcaniclastics are preferentially lost during drilling compared to biogenic sediment. If this estimate is correct, it also suggests that a large portion of unrecovered material is represented by biogenic sediment.

Most laminated beds face northwest. The stratigraphic plane azimuths show three major orientations: (1) $270^{\circ}$ to $300^{\circ}$, mainly influenced by the southwestern submarine flank of Gran Canaria; (2) $040^{\circ}$ and $220^{\circ}$, likely related to sediment mass flows moving downslope from the upper flanks of Gran Canaria; and (3) $340^{\circ}$, which has no satisfactory explanation.
\end{abstract}

\section{INTRODUCTION}

Located $45 \mathrm{~km}$ southwest of the coast of Gran Canaria, $57 \mathrm{~km}$ southeast of Tenerife, and $200 \mathrm{~km}$ west of the African continental margin, Hole 956B was drilled into the southwestern peripheral volcanic apron of Gran Canaria, in a fairly flat area close to the basement of the island, at a water depth of $\sim 3450 \mathrm{~m}$ (Fig. 1). Hole 956B penetrated a total of $700 \mathrm{~m}$ of biogenic sediment and volcaniclastic facies. The objective for this site was to demonstrate that the compositional evolution, growth, and mass wasting of an oceanic island are reflected in the sediments of the volcaniclastic apron. The sedimentary sequence recovered at Site 956 shows an excellent first-order correlation to the geological history of Gran Canaria, representing chiefly the basaltic shield (subaerial history $\sim 14.5-15.5 \mathrm{Ma}$ ) and overlying rhyolitic (14-13.3 Ma) and trachyphonolitic (13.3-9.0 Ma) pyroclastic formations (Schmincke, 1982). All of the major volcanic and nonvolcanic phases on this island are reflected in the ages, types, and compositions of sediments. The subaerial-submarine correlation was successful because of the geochemically distinct phases of volcanism on Gran Canaria and because the overall land-based stratigraphy has been documented in detail.

The aim of this study is to document the capability of downhole electrical measurements in discriminating between the volcanic and nonvolcanic sediment layers that constitute the volcanic apron of Gran Canaria. The combination of a genetic $\log$ (Schmincke, Weaver, Firth, et al., 1995) derived from core records and high-resolution electrical images obtained by the Formation MicroScanner (FMS) has allowed us to address the main problem encountered in correlating electrical and geological data. This is the lithologic discrimination from geophysical measurements. The desired outcome of such a correlation would be a methodology leading to a mass assessment of volcanic material wasted (eroded) from oceanic islands and deposited in the deep water abyssal plain.

${ }^{1}$ Weaver, P.P.E., Schmincke, H.-U., Firth, J.V., and Duffield, W. (Eds.), 1998. Proc. ODP, Sci. Results, 157: College Station, TX (Ocean Drilling Program).

${ }^{2}$ GEOMAR, Wischhofstraße 1-3, D-24148 Kiel, Federal Republic of Germany. Nicolas.Binard@t-online.de

\section{DOWNHOLE FMS MEASUREMENTS}

The FMS is a 6-m-long cylindrical measuring device that is lowered to the bottom of the drill hole, where it opens out like an umbrella, forcing four orthogonal pads against the borehole wall. The FMS tool creates an image of the borehole wall by mapping its electrical conductivity using an array of 16 small pad-mounted electrodes (Lüthi and Banavar, 1988; Pezard et al., 1990, 1992). A single pass

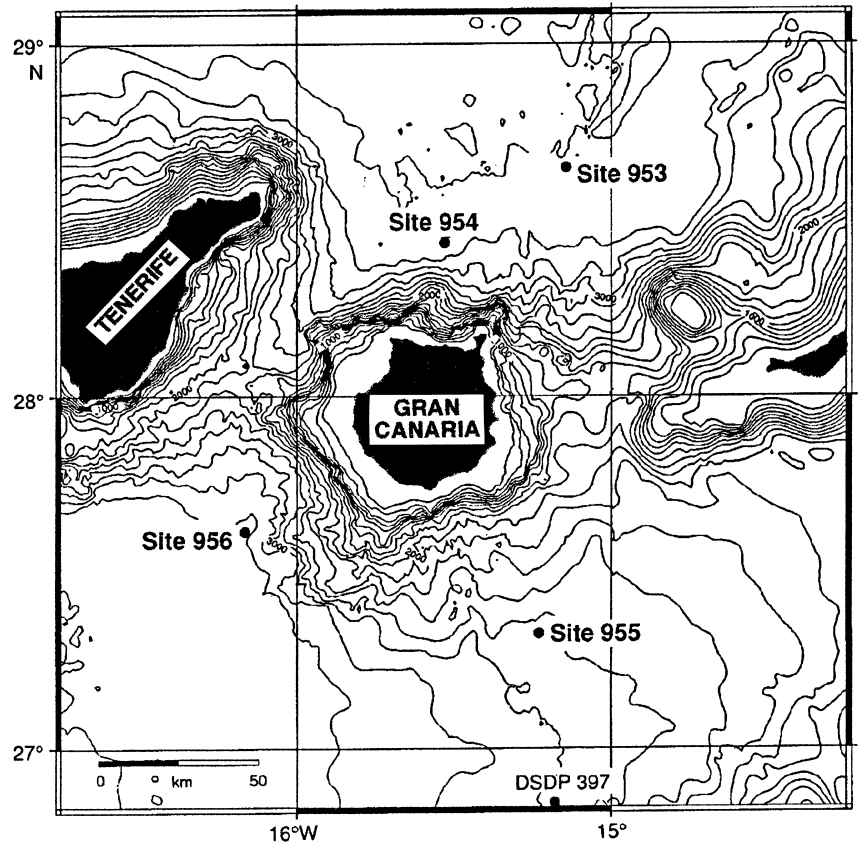

Figure 1. Bathymetric map of the central Canary Islands. Contour interval is $200 \mathrm{~m}$. Black areas = subaerial part of the volcanos, and dots $=$ location of Volcanic Island Clastic Apron Project sites. 
of the tool maps is $\sim 22 \%$ of a standard $25.4-\mathrm{cm}$-diameter borehole. FMS data are sampled every $2.5 \mathrm{~mm}$ as the tool is pulled up. The standard vertical resolution of FMS is estimated at $\sim 6 \mathrm{~mm}$.

The FMS measurement is based on a constant difference of electrical potential between the electrodes and a single return electrode. As the conductivity of the sediment varies in front of the electrodes during recording, a variable current is injected for each electrode in the formations to satisfy the constant potential condition. This current is measured and transformed into an electrical conductivity. Because the difference in potential between the electrodes varies, the image does not represent a true map of electrical conductivity of the borehole wall. Also, the processing includes a normalization procedure to optimize contrast; the gray scales are qualitative. The FMS conductivity values are given in millimhos per meter. They range from 2000 to 9000 millimhos $/ \mathrm{m}$.

The borehole section successfully logged at Site 956 ranges from 157.1 to 703.5 meters below seafloor (mbsf; Schmincke, Weaver, Firth, et al., 1995). The total length of cored section in this interval is $546.4 \mathrm{~m}$, but the total core recovered was only $297.4 \mathrm{~m}$, representing a recovery rate of $54.4 \%$. FMS data were recorded during two passes, 701 to 325 mbsf, and 701 to 283 mbsf. Between 445 and 283 mbsf, the poor-quality signal of the FMS measurements could be related to inadequate pad contact caused by degraded borehole walls. However, the corresponding sedimentary sequence is made up almost exclusively of clayey nannofossil mixed sedimentary rocks showing mottling, abundant bioturbation, slump folds, and convoluted beds, which may have contributed to the perturbations in electrical measurements.

The FMS electrical conductivity is a function of grain size, porosity, cementation, induration, and mineralogy, as well as borehole size, shape, and irregularities in the borehole wall. For clastic sedimentary rocks of similar mineralogy, cementation, and fluid type, the pixel tone on the FMS images was determined to be mainly a function of grain size (Pezard et al., 1992). The dark tones represent finegrained sedimentary rocks, whereas light tones correlate with coarsegrained sandstone. Although no general relationship exists between electrical conductivity and grain size, graded sandstone layers from turbidite sequences are usually associated with a progressive change in the conductivity imaged by the FMS. Unfortunately, in Hole 956B, biogenic rocks and volcaniclastics are intimately mixed in many beds. Variations of the many independent parameters do not allow a simple correlation between grain-size or porosity and electrical conductivity. Direct comparisons between FMS records and lithologic data confirm, however, that coarse-grained layers, such as volcanic breccia, could be matched with light-tone sections from FMS images. Therefore, at a superficial level, the FMS images provide a strip record of both texture and sharpness of contact between beds of different electrical susceptibility.

\section{Representative Microconductivity}

The first step in processing FMS data was to obtain the most representative electrical conductivity value for each sampling interval along the borehole. FMS images are constructed from 64 conductivity measurements, at a sampling interval of $2.5 \mathrm{~mm}$. Our approach to establishing a correlation between FMS records and lithologic formations does not require data from four pads. We, therefore, decided to process only the measurements obtained from Pad 2. This choice was also influenced by the good quality of Pad 2 images displayed on a computer screen.

Also, only the 10 central measurements of the 16 microconductivity values generated by Pad 2 were considered. This is because data obtained from the electrodes located on the pad borders could contain errors because of current leaks and other types of interference with the surrounding environment.
The surface of the borehole wall in contact with the FMS electrodes is very small. Minor change in porosity, mineralogy, or surface texture may lead to great variations in electrical microconductivity. This is especially true for volcaniclastics containing zeolites, vesicles, and various alteration products. A single or "representative" value of FMS microconductivity for every $2.5-\mathrm{mm}$ sampling interval has been estimated from the median, instead of the mean, of the 10 central measurements. The median was used to prevent abnormal measurements from dramatically affecting the representative value.

The vertical resolution of individual structures and features on the borehole wall is $\sim 10 \times$ the FMS sampling rate, or $2.5 \mathrm{~cm}$ (Hiscott et al., 1992). To fit this observation, several sets of data were obtained for sampling intervals of $2.5,10,20,60,120,240$, and $480 \mathrm{~cm}$.

\section{LITHOLOGIC FORMATIONS}

The volcanic and biogenic sediments are not uniformly distributed in the core, but are irregularly intermixed. They form sequences ranging from a few meters to $>150 \mathrm{~m}$ thick (Table 1). The FMS measurements corresponding to each sequence have been sorted into the following three categories: biogenic sediment, volcanic breccia, and tuffs (fine-grained volcanics), based on the core data. The categories are named from the most representative $(80 \%-90 \%)$ lithologic formation in each section. The very good correlation in depth $(<2 \mathrm{~m})$ between $\log$ and core data, allowed us to define sections almost consisted by one of the three sediment types (Fig. 2).

Quantitative or qualitative analysis of FMS data is difficult because the microconductivity is linked to independent variations of several parameters, the most important being porosity. However, such analysis could certainly be successful for sediments with very different degrees of porosity (i.e., massive lava flow and coarse biogenic sediment). In the present study, the volcanic apron consists of fine-grained volcaniclastic and biogenic sediments with similar microconductivities.

Nevertheless, FMS values for $2.5-\mathrm{cm}$ sampling intervals were plotted on a cumulative percentage curve and on a frequency diagram. The cumulative curve obtained from unsorted data clearly shows two main families: biogenic sediment with higher FMS values, and volcaniclastics with lower FMS values (Fig. 3A). The latter was divided into two categories: tuffs and volcanic breccia, based on the lithologic description. The frequency histogram of unsorted FMS data also shows a bimodal distribution corresponding to volcanic and biogenic sediments (Fig. 3B). As suggested by the cumulative curve, tuffs and volcanic breccia could not be distinguished from each other on such a diagram. Their electrical conductivities are too close to be easily differentiated.

Table 1. Depth boundaries of the main lithologies in Hole 956B.

\begin{tabular}{ll}
\hline $\begin{array}{l}\text { Depth } \\
\text { (mbsf) }\end{array}$ & \multicolumn{1}{c}{ Main formation } \\
\hline 303 & Biogenic sediment \\
450 & Fine-grained volcaniclastics \\
464 & Biogenic sediment \\
488 & Fine-grained volcaniclastics \\
493 & Biogenic sediment \\
571 & Fine-grained volcaniclastics \\
575 & Volcanic breccia \\
579.5 & Fine-grained volcaniclastics \\
582 & Biogenic sediment \\
583 & Fine-grained volcaniclastics \\
598 & Volcanic breccia \\
612 & Fine-grained volcaniclastics \\
616 & Biogenic sediment \\
619 & Fine-grained volcaniclastics \\
649 & Basaltic debris flow deposits and minor turbidites \\
701 & \\
\end{tabular}



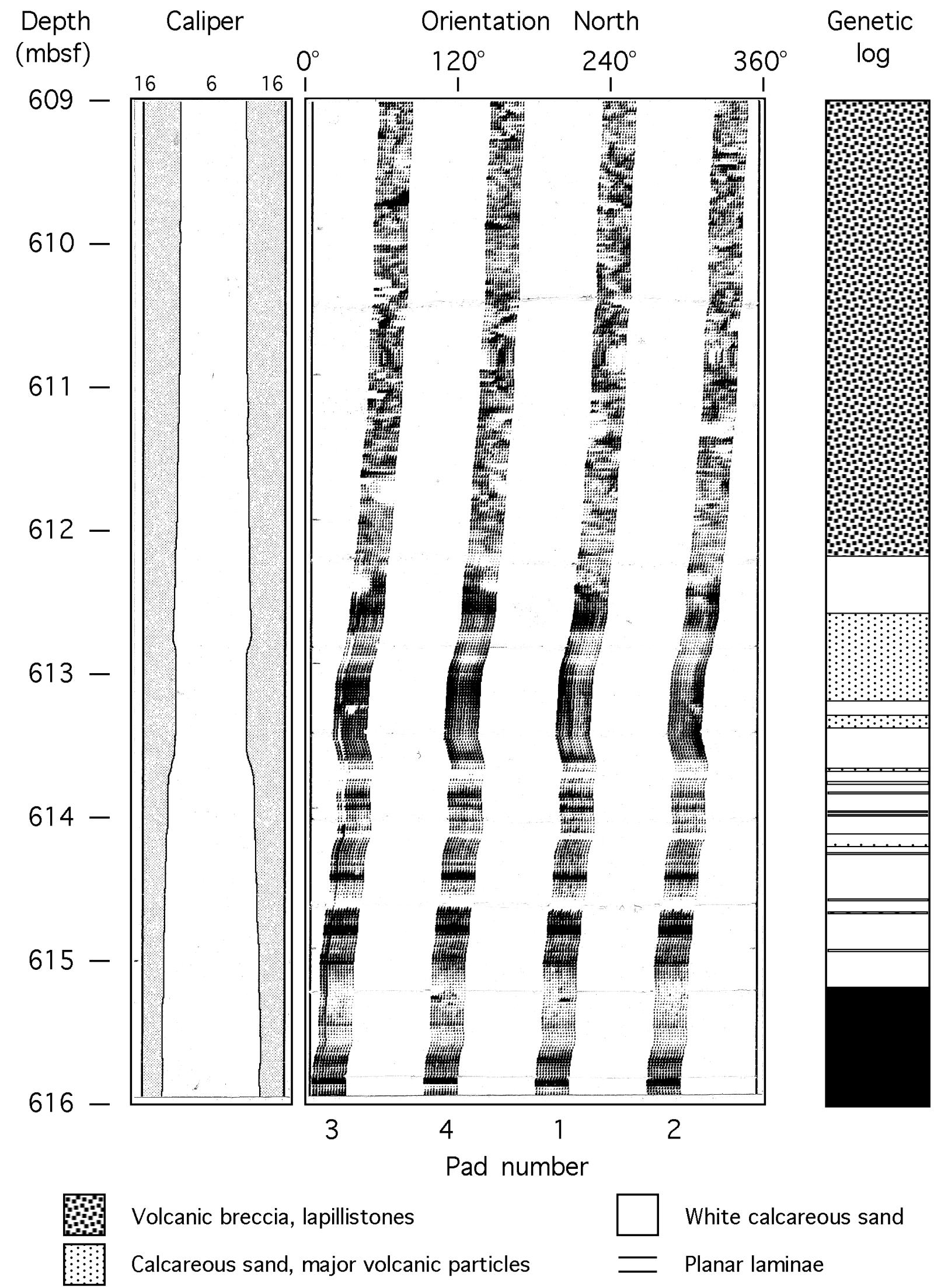

Figure 2. FMS image of volcanic breccia and biogenic sediment, Hole 956B. The underlying sediment consists of laminated beds of calcareous sand. 

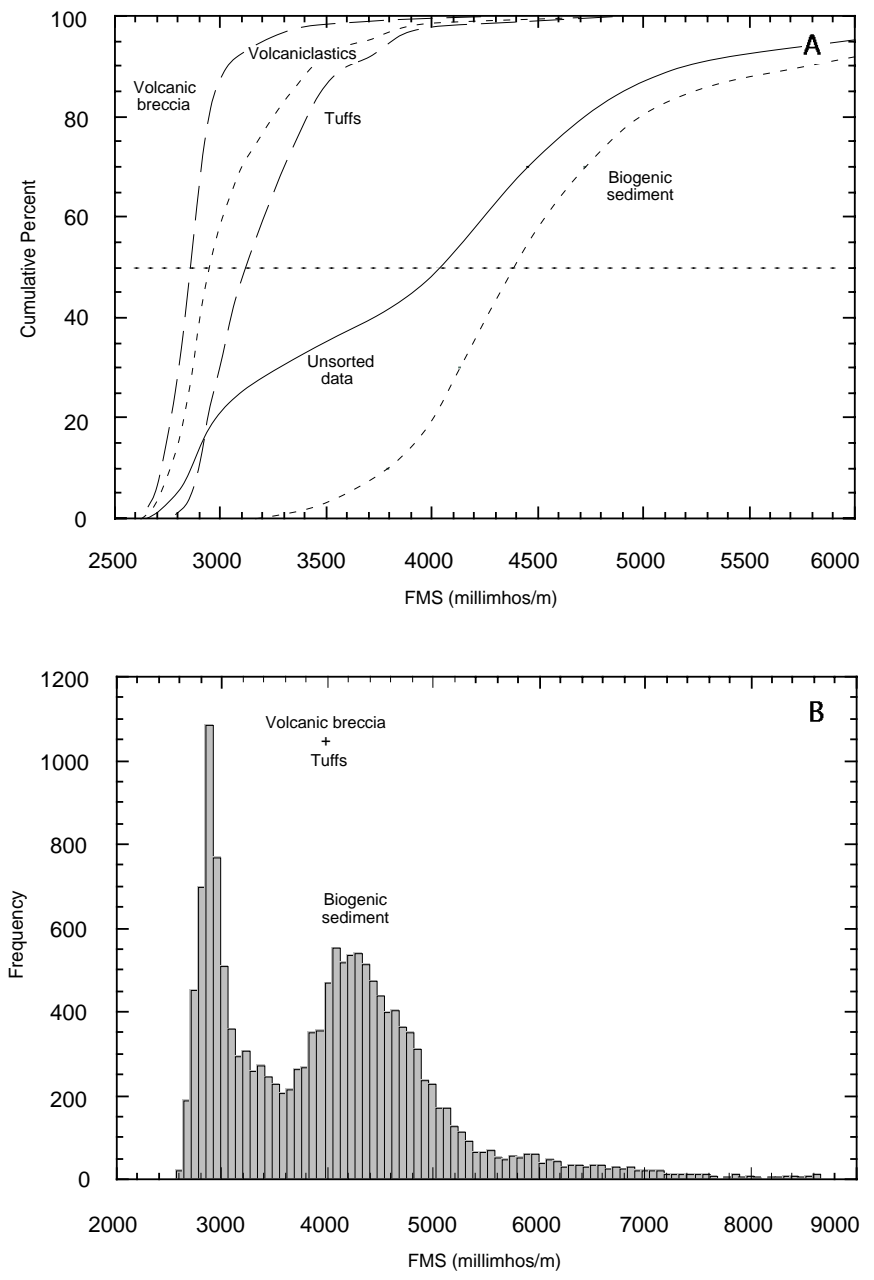

Figure 3. A. FMS characteristics of the main lithologies observed at Hole 956B. Unsorted data represent all measurements that could not be divided into the sediment and the volcanic curves. From the volcanics curves, the fine-grained tuffs and coarse-grained debris-flow deposits were distinguished. B. The frequency histogram shows a bimodal distribution of the FMS data between volcanics and biogenic sediments.

\section{Volcanic Breccia}

Volcanic breccia shows a distinct electrical conductivity signature (Fig. 4A). It ranges mainly from 2500 to $3500 \mathrm{millimhos} / \mathrm{m}$ on the FMS scale, following a power-law distribution with a maximum frequency at 2850 millimhos $/ \mathrm{m}$. The relatively narrow distribution of FMS values could be caused by the homogeneous grain size of the breccia and its generally massive structure. At a larger scale $(60 \mathrm{~cm})$, the occurrence of volcanic breccia correlates with drastic increases in electrical resistivity recorded by the spherically focused resistivity measurement.

\section{Biogenic Sediment}

The distribution of FMS values for biogenic sediments approximately follows a power-law function, with a maximum frequency at $\sim 4200$ millimhos/m (Fig. 4B). However, the number of FMS values $>4200$ millimhos $/ \mathrm{m}$ is greater than that predicted by a power law. A higher electrical conductivity could be related to either higher porosity, involving increasing water content in the sediments, or a higher concentration of clay. Conductivity of biogenic sediments is statistically higher than that of volcaniclastic sediments.

\section{Tuffs}

The FMS values showing the maximum frequency for tuffs is $\sim 2900$ millimhos/m, similar to that of volcanic breccia (Fig. 4C). However, the diagram clearly shows a large extension to higher FMS conductivity. A higher degree of porosity of the tuffs, especially finegrained vitric ashes, involving a higher water content and may be a higher concentration of clayey material caused by alteration, is likely to be responsible for this extension.

\section{VOLCANIC-BIOGENIC DIFFERENTIATION}

The FMS electrical conductivities characterizing the volcaniclastic sediments (tuffs and breccia) and biogenic sediment could be distinguished on a frequency histogram (Fig. 3B). However, they are close enough to overlap (Fig. 4D). Conductivities $>3500 \mathrm{millimhos} / \mathrm{m}$ are more representative of biogenic sediments than volcaniclastics, based on core-log integration. Conductivities <3500 millimhos/m are more characteristic of volcaniclastics. This statistical value could be used at Hole 956B to distinguish a field of volcaniclastics from that of a biogenic sediments (Fig. 5).

\section{Sediment Compaction}

Clastic sediments consist of grains forming a framework of separate clasts in a matrix. The matrix in the volcanic-apron sites is generally nannofossil mud with varying proportions of fine-grained ash or detrital clay and silt. The pores may be open or filled with matrix or chemical cement, commonly zeolites, carbonate, or clay. Lithostatic pressure results in a mechanical compaction of the framework, also dissolution and redeposition, and a concomitant decrease in sediment porosity. The electrical conductivity is very sensitive to compaction. The effect of sediment compaction were observed on a FMS conductivity vs. depth diagram (Fig. 6). The progressive decrease with depth in electrical conductivity of biogenic materials from Hole $956 \mathrm{~B}$ is evidenced by a negative linear correlation. Such a relationship could only be modeled from a coherent set of measurements made on biogenic material, which is fairly homogeneous, consisting largely of clay-sized nannofossil ooze. Nevertheless, the plot shows large variations of the FMS values, especially at depths shallower than 450 mbsf. In contrast, volcaniclastic sediments represent heterogeneous material showing great variations in grain size and shape and chemical composition, and should not be considered for compaction measurements, at least on a scale of a couple hundred meters. Compaction is certainly the most important factor causing the spread in the distribution of FMS conductivity, as observed on frequency histograms (Fig. 4A-C).

\section{QUANTITATIVE ESTIMATE OF VOLCANICLASTICS}

Different methods have been tested to estimate the relative abundance of volcaniclastic and biogenic sediments. The poor quality of FMS data above 445 mbsf did not permit us to use them for such an estimate. Moreover, core data show that this section consists exclusively of biogenic sediments, which makes it useless for estimating the proportion of volcaniclastics.

Table 2 summarizes the principal results obtained with different methods. Based on core data, $53.8 \%$ of the recovered material between 445 and 701 mbsf consists of volcanic sediments, but this percentage is representative of only $46.6 \%$ (recovery rate) of the drilled 

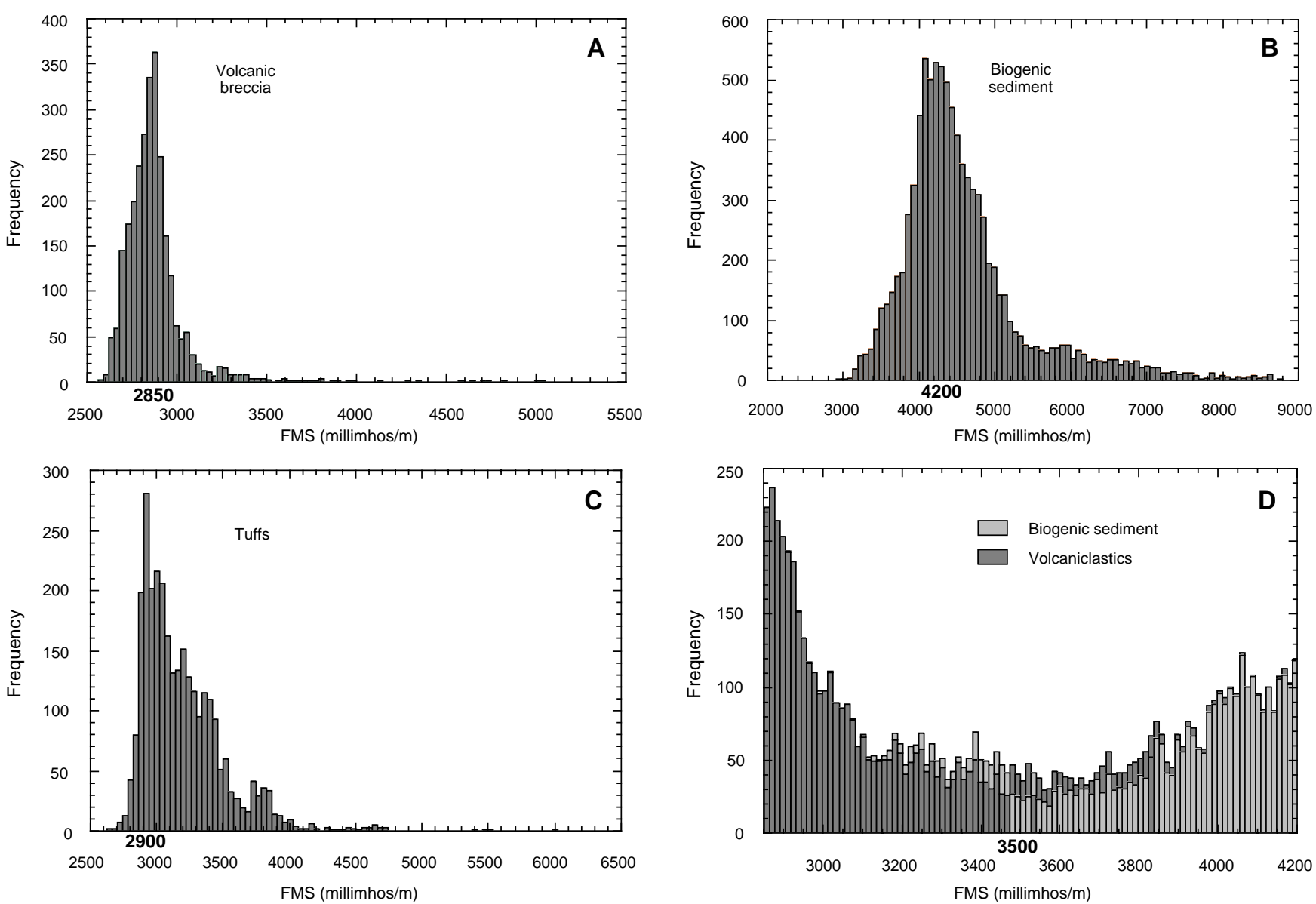

Figure 4. Frequency histograms for FMS conductivity. Bold numbers = maxima. A. Volcanic breccia and lapillistones. B. Biogenic sediment. C. Fine-grained volcaniclastic material. D. Detailed frequency histogram for overlapping FMS conductivities between fine-grained volcaniclastic and biogenic sediment.

section. A high degree of uncertainty remains, especially because the unrecovered material is believed to be mostly volcaniclastics having a low degree of coherence (unlithified ashes, pumice, and lapilli, etc.), whereas biogenic sediment always has close to $100 \%$ recovery rate.

The second method, based on the measured electrical conductivity of the sediments, appears to be the most valuable method. About $54.9 \%$ of the total FMS values are $<3500 \mathrm{millimhos} / \mathrm{m}$ and represent volcaniclastics. The percentage is a bit higher but still comparable to that derived from the core estimate in light of the fact that volcaniclastics are preferentially lost during drilling compared to biogenic sediment. If this estimate is correct, it also suggests that a relatively large portion of unrecovered material is represented by biogenic sediment. Biogenic sediment layers are coherent only if the layers are thick enough. Biogenic sediments in the apron of Gran Canaria are frequently interrupted by tuffs and lapillistones, decreasing the coherence of beds and resulting in a lost of biogenic material with drilling fluids. Thin biogenic beds are probably smashed to bits by the drilling.

\section{STRATIFICATION}

Two main types of stratigraphic features observed in the cores have been imaged by FMS. The first consists of contorted and folded beds of clayey nannofossil mixed sediment in the upper part of the logged interval, between 283 and 370 mbsf. The second is characterized by laminated beds of biogenic and volcaniclastic sediments. Volcanic breccia are dominantly massive. Only laminated beds were analyzed, representing volcaniclastic sediments discussed in detail by Sumita and Schmincke (Chap. 15, this volume) and Schmincke and Sumita (Chap. 16, this volume).

The parallel laminations are almost flat. Azimuth and dip could only be measured with confidence at a work station. Because of good FMS image quality and high resistivity contrast, the parallel laminations are generally visible in all four image strips. When visible, a sinusoid was fitted to the dipping lamination and forced through the same level on the four imaged sides of the borehole, thus defining a plane with an azimuth and a dip. The image processing program was able to enhance the vertical scale to make accurate measurements. The operation was repeated as often as laminations were observed, permitting us to collect 615 stratigraphic planes between 300 and 700 mbsf.

Azimuths of recorded stratigraphic planes from Hole 956B are plotted as a rose diagram (Fig. 7A). Most laminated beds face northwest, between azimuths $270^{\circ}$ and $300^{\circ}$, which is not in agreement with the relative position of the subaerial part of Gran Canaria (Fig. 7B). The borehole is located on the southwestern flank of the island, and the majority of the laminated beds should group in the same direction. In fact, bathymetric data show that the southwestern submarine flank of the island at Hole 956B contains a sharp topographic high trending southwest, probably a rift zone that probably deflects 


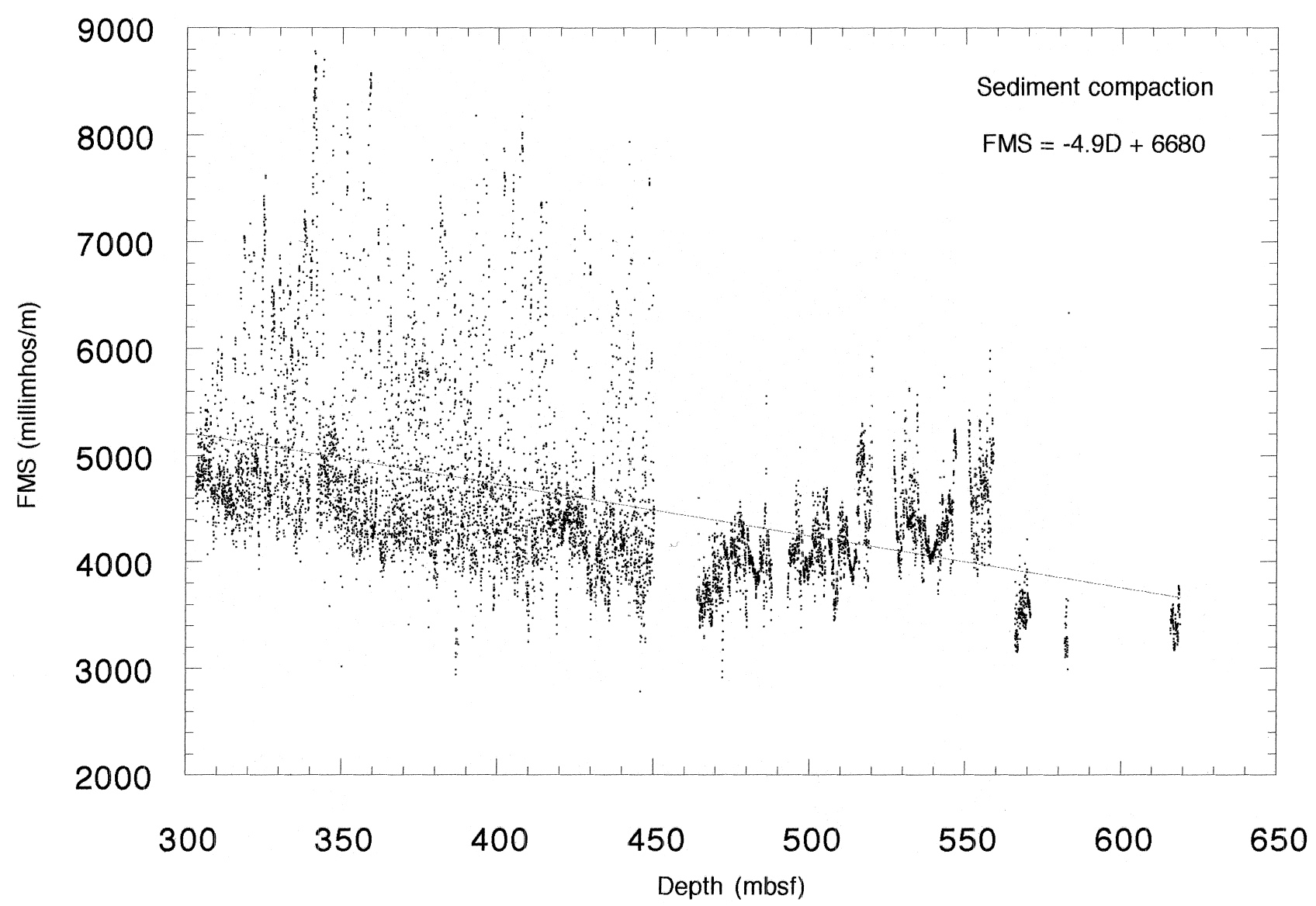

Figure 5. FMS data vs. depth diagram. Sampling interval is $2.5 \mathrm{~cm}$. The statistical FMS value of 3500 millimhos/m limits the "volcanics" field and the "biogenic sediment" field.

the turbidite flows (Fig. 1). Hole 956B was drilled into an area of the Canaria Channel mainly influenced by this southwestern submarine zone. Consequently, the general orientation of the beds is northwest.

Two other directions were easily identified. One is characterized by azimuths $040^{\circ}$ and $220^{\circ}$. The stratigraphic planes belong to the same family, dipping either east or west, and could be related to sediment mass flows (debris) moving downslope from the upper flanks of Gran Canaria. Another orientation of $340^{\circ}$ remains unexplained.

Bed azimuths show no correlation to depth, suggesting that most of the stratigraphic pile is made of intermixed material coming from different directions or sources (Fig. 8). However, Figure 8 clearly shows that biogenic and volcaniclastic sediments group into a sector $\sim 180^{\circ}$ wide, between azimuths $250^{\circ}$ and $350^{\circ}$, at depths deeper than $450 \mathrm{mbsf}$. Above $450 \mathrm{mbsf}$, where no substantial volcaniclastic material were recovered, laminated biogenic beds are randomly oriented.

\section{CONCLUSIONS}

The purpose of the study was to find particular feature of the FMS electrical conductivity that would allow us to differentiate between volcaniclastic and biogenic materials in Hole 956B. Unfortunately, it was not possible to unequivocally identify the lithology of laminated beds making up the archipelagic apron of Gran Canaria. The main problem is that the electrical conductivity measured by FMS depends on too many independent parameters. It has been shown that clayey nannofossil sediment can be easily distinguished from coarse volca- nic breccia, because the absolute conductivity value differs significantly between these two lithologies (Fig. 5). The measured electrical conductivity value allows an estimate of the relative amount of volcaniclastic layers as $\sim 55 \%$ by volume, between 445 and $701 \mathrm{mbsf}$ in the southwestern archipelagic apron of Gran Canaria. However, the distinction between biogenic and volcanic layers is problematical because variations in FMS measurements have the same order of magnitude within a monolithologic layer as between two layers with different lithologies.

\section{ACKNOWLEDGMENTS}

This research was supported by DFG grants Schmincke 250/41-1 and 250/60-1. We thank Philippe Pezard and his staff from the "ODP Logging Laboratory" of Marseille, for their hospitality and their help in processing FMS data. We are particularly indebted to the Department of Volcanology and Petrology of GEOMAR, whose laboratory facilities helped us complete this work. We are thankful to Peter Clift, Carlos A. Conçalves, and an unknown reviewer for critical review and suggestions that helped to improve the manuscript.

\section{REFERENCES}

Hiscott, R.N., Colella, A., Pezard, P., Lovell, M.A., and Malinverno, A., 1992. Sedimentology of deep-water volcaniclastics, Oligocene Izu-Bonin forearc basin, based on formation microscanner images. In Taylor, B., Fujioka, K., et al., Proc. ODP, Sci. Results, 126: College Station, TX (Ocean Drilling Program), 75-96. 
Lüthi, S.M., and Banavar, J.R., 1988. Application of borehole images to three-dimensional geometric modeling of eolian sandstone reservoirs, Permian Rotliegende, North Sea. AAPG Bull., 72:1074-1089.

Pezard, P., Lovell, M., and ODP Leg 126 Shipboard Scientific Party, 1990. Downhole images: electrical scanning reveals the nature of subsurface oceanic crust. Eos, 71:709, 718.

Pezard, P.A., Lovell, M.A., and Hiscott, R.N., 1992. Downhole electrical images in volcaniclastic sequences of the Izu-Bonin forearc basin, western Pacific. In Taylor, B., Fujioka, K., et al., Proc. ODP, Sci. Results, 126: College Station, TX (Ocean Drilling Program), 603-624.

Schmincke, H.-U., 1982. Volcanic and chemical evolution of the Canary Islands. In von Rad, U., Hinz, K., Sarnthein, M., and Seibold, E. (Eds.),
Geology of the Northwest African Continental Margin: Berlin (Springer), 273-306.

Schmincke, H.-U., Weaver, P.P.E., Firth, J.V., et al., 1995. Proc. ODP, Init. Repts., 157: College Station, TX (Ocean Drilling Program).

Date of initial receipt: 3 July 1996

Date of acceptance: 8 March 1997

Ms 157SR-138

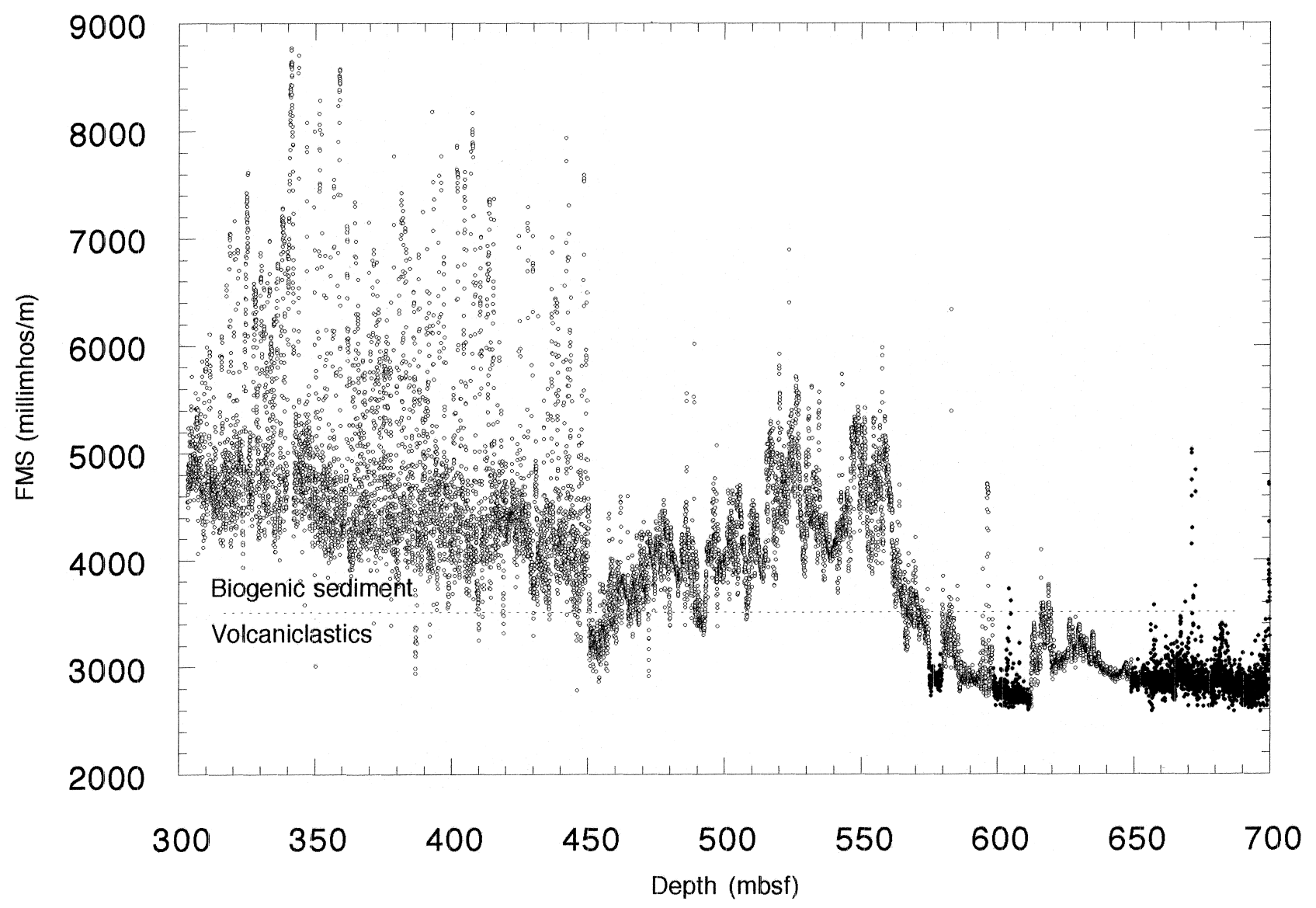

Figure 6. FMS data vs. depth for biogenic sediments. Sampling interval is $2.5 \mathrm{~cm}$. The compaction effect due to depth involves a decrease in sediment porosity reflected in a progressive decrease in electrical conductivity. Solid circles $=$ volcanic breccia. 
Table 2. Relative abundance of volcaniclastics and sediment in Hole 956B between 445 and 701 mbsf.

\begin{tabular}{lcc}
\hline & \multicolumn{2}{c}{ Estimated proportions (\%) } \\
\cline { 2 - 3 } \multicolumn{1}{c}{ Lithology } & Core & FMS conductivity \\
\hline Volcaniclastics & 53.8 & 54.9 \\
Biogenic sediment & 46.2 & 45.1 \\
\hline
\end{tabular}

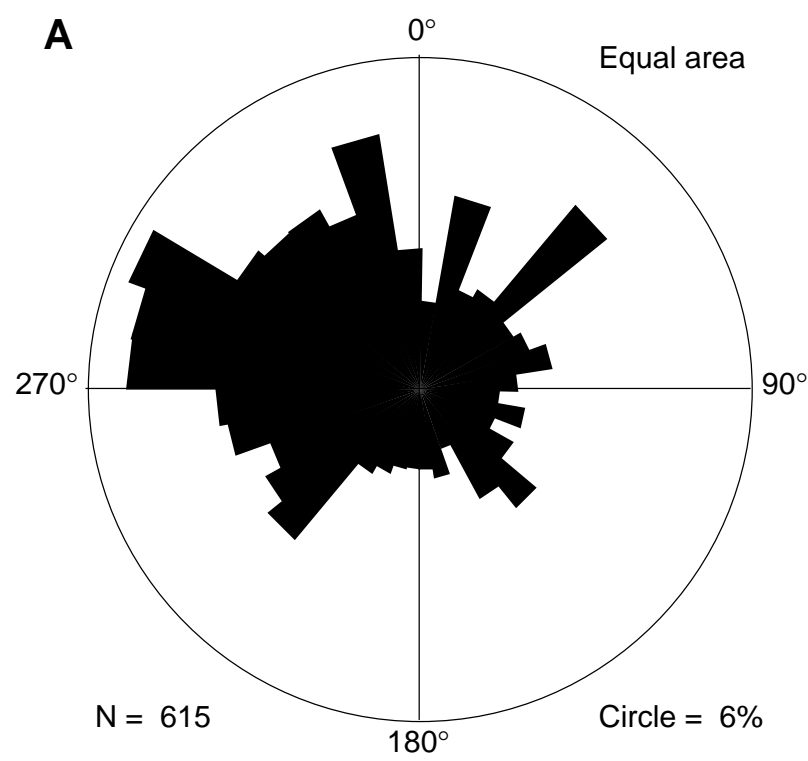

B

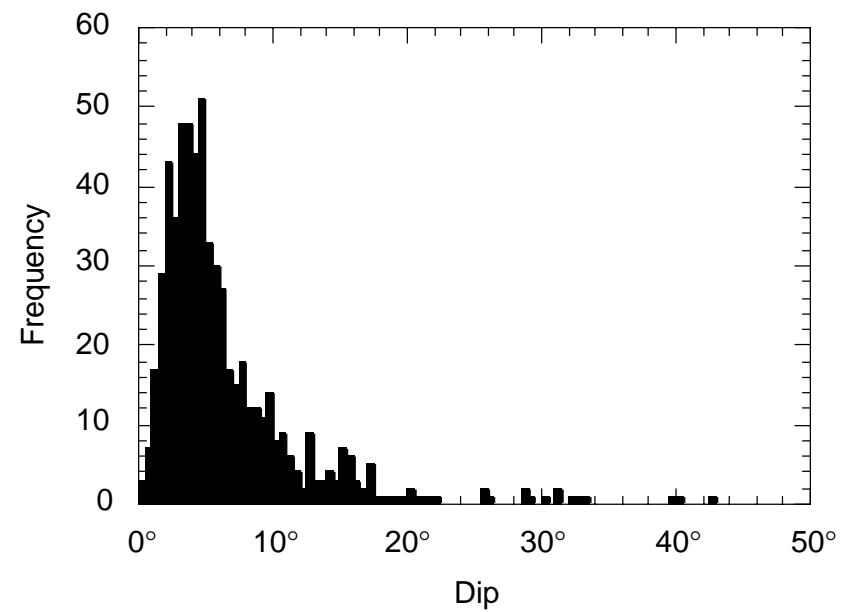

Figure 7. A. Rose diagram of azimuth directions for computed-fitted planes derived from FMS images in nannofossil mud and volcaniclastic sediments from Hole 956B. N = number of data points. B. Histogram of plane dips.

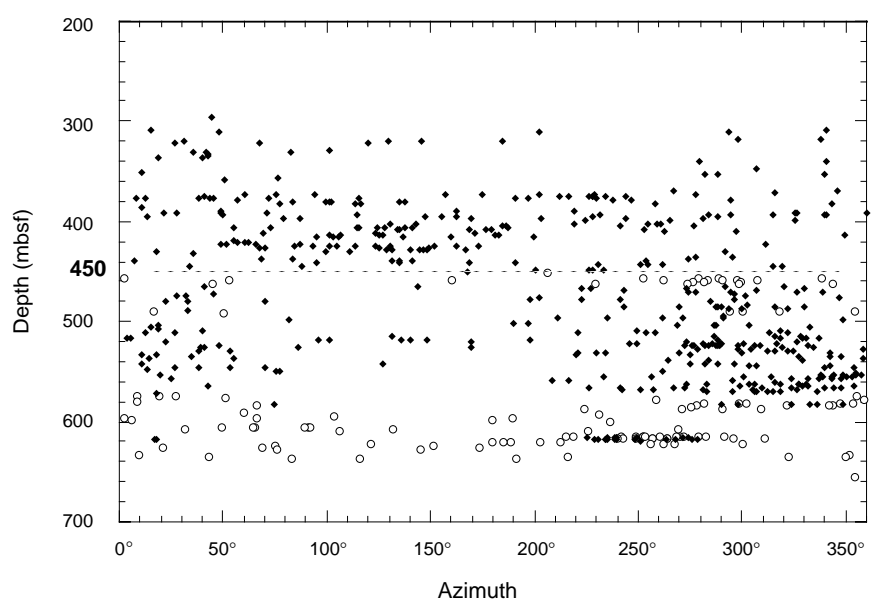

Figure 8 . Diamonds $=$ depth vs. azimuth diagram for biogenic sediments, and circles $=$ volcaniclastic beds . Below 450 mbsf, plane azimuths range from $250^{\circ}$ to $350^{\circ}$. This direction is not represented at a shallower depth. 